\title{
Dynamics and Place of the Personal Income Tax in Albanian Economy
}

\author{
Dr. Ines Nurja \\ Dean in Economics and Finance Department, University of New York Tirana \\ Lecturer at the University of Tirana
}

\section{Doi:10.5901/ajis.2016.v5n3p25}

\begin{abstract}
This paper will address the role and importance of fiscal policy in the Albanian economy during the transition period. Fiscal policies implemented during this period were different, depending on the programs of political parties that have governed. Generally, the analysis is focused on the PIT indicator (Personal Income Tax). Analyze the dynamics of income from PIT by these indicators; PIT revenues for ALL (leks) of GDP, income from PIT for ALL income tax, income from PIT for ALL income from taxes and customs etc. According years are reflected decisions and rate of change of the structure of PIT. It is analyzing the dynamics and the degree of relatedness between PIT and GDP (in percentage and in absolute figure). The aim is to analyze the degree of relatedness between PIT and GDP, so that in the future Fiscal Policy (PIT) affect more in the growth of GDP. Conclusions that have emerged from this analysis are: PIT is the tax that has changed more than any other tax, 9 times, almost every 2.8 years. There is strong correlative link between her and the dynamics of GDP in percentage and in absolute figure. This is because PIT is reflected in G (government purchases), and G is part of GDP. It is recommended not to change often the PIT rate, because frequent changes have a negative impact on the performance of revenue collection. In this paper, they used methods description, comparison, analysis, synthesis, statistics etc.
\end{abstract}

Keywords: GDP (Gross Domestic Product), PIT (Personal Income Tax), economic growth, income and government spending

\section{Introduction}

Albania for a period of 45 years has been State of the proletarian dictatorship. There was no private property. Everything was state property. The economy has been fully centralized and based on the principles of socialist planning such as: support on its own forces, democratic centralism, the line of people, proletarian partisanship etc. Everything was planned, there was no market concept, the concept of supply and demand. Economic phenomena such as inflation and unemployment were not known. These phenomena were regarded as capitalist economies features, and not socialist economies. There were no concepts for taxes and fees, etc. This type of system and organization failed in Albania, as in all East. At the end of 1990, the Albanian economy was almost completely disorganized and destroyed, and a biblical exodus. With these conditions, the Albanian economy was introduced in 1991.

To overcome this situation should: create the new parliament of free and democratic elections, which would create a new government. In this period stood before parliament and government a very important set of tasks;

- to fulfill the privatization of land and all other means of production that had been owned by the state,

- restructured and privatized financial system in order to support the new economy,

- state administration should be reorganized,

- $\quad$ they should be approved new legislative packages that adapt to the new form of property, etc., etc.

In this context, great importance to receive the approval of the legal framework of Taxation. It should be created, structured and organized Department of Taxation (as separate units) for which there was no kind of experience. The revenues collected it will be the main source of the functioning of the new government. Albanian Government in drafting laws in general, and in particular the fiscal system, relied on western European legislation. This action, regardless of rate changes over the years, show that it was vital. In this paper we will analyze the dynamics of the Personal Income Tax, which is one of the most important tax system. This is the tax that has changed more, and is more controversial

\section{Changes in Legislation PIT (Personal Income Tax) 1992-2015.}

After 1992, the tax system was created that will suit the market economy. Thus, for the first time after 45 years of economic entities would be subject to taxation. On the basis of the tax system they were awarded the laws of Western Europe. Initially it implemented a significant tax package as Personal Income Tax, Profit Tax, Income Tax, Excise etc. 
Only in 1996 it was implemented on Value Added Tax (VAT). PIT set and implemented as a progressive tax. This progressive tax, in our opinion, had not applied since the beginning of reform, because people were introduced to the market economy, income and almost equal wages. And in this time period should apply Flat Tax. When the society was divided by income groups with low income, middle income, high income, then tax should be applied progressively. Below given PIT dynamics of laws by the time of the change.

Table 11. Income Tax (July 1992)

\begin{tabular}{|c|c|c|c|c|c|}
\hline No & Salary & Taxable Base & $\%$ & Tax & Tax \\
\hline 1 & -2500 & & 0 & 0 & 0 \\
\hline 2 & $2501-3000$ & Over 2500 & 10 & 50 & 50 \\
\hline 3 & $3001-3500$ & $2501-3000$ & 10 & 50 & 100 \\
\hline 4 & $3001-3500$ & $3001-3500$ & 20 & $100+100$ & 200 \\
\hline 5 & Over 3501 & Over 3501 & 30 & $200+$ & $200+$ \\
\hline
\end{tabular}

Before 1990, workers' wages were very low. They ranged from $4500 \mathrm{ALL}$ to $12000 \mathrm{ALL}$ (old). After 1990, prices rose several times. They continued to grow despite the income of citizens. In this way the new government was forced to increase wages, regardless of the budget situation. It must be realized, roughly, a match between the level of price increases and wage growth level. There had been four layers $0 \%, 10 \%, 20 \%$ and $30 \%$. For this reason, during the implementation of the PIT appeared many problems. In this way the government had to review again this tax. Initially there were stratified salaries to $2500 \mathrm{ALL}$ and the $3501 \mathrm{ALL}$. Every year wages increase at a high rate. This consequently brought the request for a review of the progressive tax. In this way, the minimum increased from $2500 \mathrm{ALL}$ to $4000 \mathrm{ALL}$. The maximum was increased from $3501 \mathrm{ALL}$ to over $10000 \mathrm{ALL}$. Wage differentiation became necessary because it begins functioning market economy. Revenues began to grow, increased domestic production. Albanian government in this period was credited by the IMF and other international financial organisms. After three months, the table is the income tax change again and took the form below.

Table 2². Income Tax (October 1992)

\begin{tabular}{|c|c|c|c|c|c|}
\hline No & Salary & Taxable Base & Tax rate (\%) & Tax & Tax \\
\hline 1 & -4000 & & 0 & 0 & 0 \\
\hline 2 & $4001-5000$ & Over 4000 & 5 & 50 & 50 \\
\hline \multirow[t]{3}{*}{3} & $5001-5500$ & From 4001 - 5000 & 5 & 50 & 50 \\
\hline & $5001-5500$ & Above 5001 & 10 & 50 & 100 \\
\hline & $5501-6500$ & From 4001 - 5000 & 5 & 50 & 50 \\
\hline \multirow[t]{4}{*}{4} & $5501-5500$ & From 5001 - 5500 & 10 & 100 & 100 \\
\hline & $5501-6500$ & From $5501-6500$ & 15 & 150 & 300 \\
\hline & $6500-8000$ & From 4000 - 5000 & 5 & 50 & 50 \\
\hline & $5001-5500$ & From 5001 - 5500 & 10 & 100 & 100 \\
\hline \multirow[t]{2}{*}{5} & $5501-6500$ & From 5501 - 6500 & 15 & 150 & 150 \\
\hline & $6501-8000$ & From $6501-8000$ & 20 & 300 & 600 \\
\hline 6 & $8001-9000$ & From 8001 - 9000 & 25 & 250 & 850 \\
\hline 7 & Over $\quad 9000$ & From $9000-10000$ & 30 & 300 & 1150 \\
\hline 8 & Over 10000 & Over 10000 & 40 & 400 & 1550 \\
\hline
\end{tabular}

Until 1994 it was implemented the wage table with 8 tax rate. During these years, wages grew continuously. Thus taxation from $10000 \mathrm{ALL}$ pass on $40000 \mathrm{ALL}$. In 1994 it became the next change in rates of taxation according to the following Table.

\footnotetext{
1 Law Nr.7585, dated 07.14.1992 "On Income Tax", Official Bulletin No. 4 - 1992, p. 197

2 Law Nr.7628, dated 10.21.1992 "On Amendments to the Law Nr.7585, dated 07.14.1992" On Income Tax ". Official Bulletin No. 6 1992, p. 308. 
Table 33. Income Tax (1994)

\begin{tabular}{|c|l|c|c|}
\hline No & Naming & Tax rate & Tax/ALL \\
\hline 1 & Income up to 4,000 ALL. & 0 & \\
\hline 2 & Income 4000-10000 ALL amount over 4,000 taxable 10\% & 10 & 600 \\
\hline 3 & Income 10001-20000 ALL, taxed 600 ALL + 15\% of the amount over 10,000 ALL. & 15 & 2.1 \\
\hline 4 & Income 20001-30000 ALL taxed for 2100 ALL + 20\% of the amount over 20,000 ALL. & 20 & 4.1 \\
\hline 5 & Income on 30001-40000 ALL taxed 4,100 ALL plus 25\% of the amount over 30,000 ALL & 25 & 6.6 \\
\hline 5 & Income over 40,000 ALL taxed 6.600 ALL plus 30\% of more than 40,000 ALL & 30 & 9.6 \\
\hline
\end{tabular}

Until 1994 there were 8 tax rates. With the new law set to have only 6, regardless of the maximum tax rate increased 4 times. This continued until 1996, because this year, other changes were made.

Increasing wages and incomes in general dictate the new Amendment of the PIT system. Thus, the minimum wage will not start on the 4000 ALL but will start from 10,000 lek. Max does not want me 40000 ALL, but it would be over $60,000 \mathrm{ALL}$.

Table 44. Income Tax (1996)

\begin{tabular}{|c|l|c|c|}
\hline No & Naming & Tax rate & Tax/ALL \\
\hline 1 & Income up to 10,000 ALL & 0 & \\
\hline 2 & Income 10.001-20.000ALL amounts over 10,000 ALL & 5 & 500 \\
\hline 3 & Income 20.001-30.000 ALL, taxed 500ALL + 10\% of the amount over 20,000 ALL & 10 & 1500 \\
\hline 4 & Income 30.001-60.000 ALL, taxed 1500 ALL + 15\% of the amount over 30,000 ALL & 15 & 6000 \\
\hline 5 & Income over 60,000 ALL taxed 6000 ALLplus 20\% of more than 60,000 ALL & 20 & $6000+$ \\
\hline
\end{tabular}

Another change took place in 1998 with a minimum of $10,000 \mathrm{ALL}$ and maximum over 120,000 ALL. Here we can see the big difference in the level of income. In two years we have increased the maximum taxable income by $200 \%$, from 60,000 ALL to $120,000 \mathrm{ALL}$. These changes are reflected in the income from the PIT application.

Table 55. Income Tax 1998

\begin{tabular}{|c|l|c|c|}
\hline No & Naming & Tax rate & Tax ALL \\
\hline 1 & Income up to 10,000 ALL & 0 & \\
\hline 2 & Income 10.001-20000 ALL amounts over 10,000 ALLL & 5 & 500 \\
\hline 3 & Income 20.001-30000 ALL, taxed 500 ALL + 10\% of the amount over 20,000 ALL & 10 & 1500 \\
\hline 4 & Income 30.001-50.000 ALL, taxed 1500 ALL+ 15\% of the amount over 30,000 ALL & 15 & 4500 \\
\hline 5 & Income 50.000-80.000 ALL, taxed 4500 ALL +20\% of the amount over 50,000 ALL & 20 & 10500 \\
\hline 6 & Income 80.000-120.000 ALL, taxed 10500 ALL + 20\% of the amount over 80,000 ALL & 25 & 20500 \\
\hline 7 & Income over 120,000ALL taxed 20500 plus 30\% of the amount over 120,000 ALL & 30 & \\
\hline
\end{tabular}

The next change was made in 2001 with a minimum of 14,000 and maximum over 150,000 Lek Lek. In comparison with the previous period, the difference is small, because gradually begin to stabilize the ratio of salary increases with the increase of the price level.

\footnotetext{
3 The salary table Nr.1-1994 Official Bulletin 1994, page 14.

${ }^{4}$ Law no.8901 adopted on 4/5/1996, dated 21.3.1996 "On Amendments to the Law Nr.7786, dated 27.01.1994" On Personal Income Tax "f.947 F official- No. 12 as amended by Law Nr.7897 dated 02.02.1995. In Law Nr.7786, dated 27.01.1994 "On Personal Income Tax", amended by Law Nr.7897, dated 02.02.1995.

5 Law Nr.8437, dated 28.12.1998 "On income tax", Official Bulletin no. 32-1998.
} 
Table 66. Income Tax (2001)

\begin{tabular}{|c|c|c|c|}
\hline \multicolumn{2}{|c|}{ Taxable income (per month) } & \multicolumn{2}{|c|}{ Personal Income Tax } \\
\hline Over (ALL) & Until (ALL) & Leks(ALL) & Percent \\
\hline 0 & 14000 & & Exclusive threshold \\
\hline $14000+$ & 30000 & 0 & $+5 \%$ of the amount over 14000 \\
\hline $30000+$ & 60000 & 800 & $+10 \%$ of the amount over 30000 \\
\hline $60000+$ & 80000 & 3800 & $+15 \%$ of the amount over 60000 \\
\hline $80000+$ & 100000 & 6800 & $+18 \%$ of the amount over 80000 \\
\hline $100000+$ & 125000 & 10400 & $+20 \%$ of the amount over 100000 \\
\hline $125000+$ & 150000 & 15400 & $+23 \%$ of the amount over 125000 \\
\hline $150000+$ & Over & 21150 & $+25 \%$ of the amount over 150000 \\
\hline
\end{tabular}

The next change occurred in 2006. The maximum taxable income increase by $150,000 \mathrm{ALL}$ in 200.000ALL.

Table 7. Personal Income Tax (2006)

\begin{tabular}{|c|c|c|c|}
\hline $\begin{array}{c}\text { Taxable income } \\
\text { (per month) }\end{array}$ & \multicolumn{3}{|c|}{ Personal Income Tax } \\
\hline Over (ALL) & Until (ALL) & Leks(ALL) & Percent \\
\hline 0 & 14000 & 0 & $+1 \%$ of the amount over 0 \\
\hline $14000+$ & 40000 & 140 & $+5 \%$ of the amount over 14000 \\
\hline $40000+$ & 90000 & 1440 & $+10 \%$ of the amount over 40000 \\
\hline $90000+$ & 200000 & 6440 & $+15 \%$ of the amount over 90000 \\
\hline $200000+$ & Over & 22940 & $+20 \%$ of the amount over 200000 \\
\hline
\end{tabular}

2007 brought a turning point in the tax system. For the first time Flat Tax was introduced in place of a progressive tax. The argument for establishing this tax was simple. This tax will more easily met and there would be no problems with tax evasion.

Table 87. Income tax (2007)

\begin{tabular}{|c|c|c|}
\hline Taxable income (per month) & \multicolumn{2}{|c|}{ Percent } \\
\hline Over(ALL) & Until(ALL) & zero percent \\
\hline 0 & 30 & $+10 \%$ of the amount over O ALL \\
\hline $30.001+$ & Over & \\
\hline
\end{tabular}

This tax was applied until 2013, when the government pass into the hands of the Socialist Party, which regained the progressive tax. The argument was because the flat tax are punished more layers with lower income than groups with high incomes. This tax is progressive located 2013 continues to apply today. It does not much differentiation rate. Compared with previous systems it is simple to apply.

Table 9. Taxes on income (2013)

\begin{tabular}{|c|c|c|}
\hline \multicolumn{2}{|c|}{ Taxable income (per month) } & Percent \\
\hline From & Until & zero percent \\
\hline 0 & 30.000 & $+13 \%$ of the amount over $30.000 \mathrm{ALL}$ \\
\hline 30.001 & 130.000 & $13.000 \mathrm{ALL}+23 \%$ of the amount over $130.000 \mathrm{ALL}$ \\
\hline 130.001 & Over & \\
\hline
\end{tabular}

${ }^{6}$ Law Nr. 8841, ......... For some amendments to the Law 8438, Dated 28.12.1998 "On Income Tax" Nr.8711 Amended Law, Dated 15.12.2000.

7 Official Journal Nr.90-2007 f. 2614. Law no. 9766, d.9.072007 "On some amendments to Law 8438, d.28.12.1998" On income tax ". 
Eventually the change in the tax system is adapted to change and the level of wage earnings. Below is the change of the average wage level in years, and the limits taken into consideration in return.

Year / Salary
1992
1992
1994
1996
1998
2001
2006
2007
2013
2014
2015

\begin{tabular}{|c|c|c|}
\hline Minimum & Maksimum & Average salary \\
\hline 2500 & over 3500 Lek(ALL) & $1.783 \mathrm{Lek}$ (ALL) \\
\hline 4000 & over 10000 ALL & $1.783 \mathrm{ALL}$ \\
\hline 4000 & over 40000 & $4.514 \mathrm{ALL}$ \\
\hline 10000 & over 60000 ALL & $8.638 \mathrm{ALL}$ \\
\hline 10000 & over $120000 \mathrm{ALL}$ & $11.509 \mathrm{ALL}$ \\
\hline 14000 & over $150000 \mathrm{ALL}$ & $17.218 \mathrm{ALL}$ \\
\hline 14000 & over $200000 \mathrm{ALL}$ & $28.822 \mathrm{ALL}$ \\
\hline Flat tax $10 \%$ & over 30000 ALL & $33.750 \mathrm{ALL}$ \\
\hline 30000 & over $130000 \mathrm{ALL}$ & $52.150 \mathrm{ALL}$ \\
\hline & & $53.025 \mathrm{ALL}$ \\
\hline & & $10 \mathrm{ALL}$ \\
\hline
\end{tabular}

The above data show the dynamics and characteristics of the PIT.

We differentiate:

a) In 24 years, PIT has changed 9 times or once every 2.8 years.

b) Only 8 years flat tax is applied. In other years the progressive tax is applied.

c) progressive tax has changed several times depending on rritjers income and wages, becoming simple.

d) PIT is differentiated during the 13 th percentile. At 0\%, 1\%, 5\%, 10\%, 13\%, 15\%, 18\%, 20\%, 23\%, 25\%, 30\%, $35 \%$ and $40 \%$. Only in 1992 were 7 levels.

e) Rate of PIT in general has increased. This indicates that fiscal policies have been styptic.

f) This tax has created difficulties in its collection because it requires skilled workers.

\section{Dynamics of Income from PIT and some Synthetic Indicators Report}

PIT rate increase, increasing the number of employees and wage growth have brought the level of income growth. This means that the increase in the taxable base and the tax rate are the basis of revenue growth from PIT. But besides them there are also other factors such as the fight against informality, which in Albania today is still at low levels. Revenues raised by PIT have had a huge increase. If in 1994 were 0.6 billion, in 2015 were 32.07 billion. They increased by 53 times. The average salary in the public sector increased from 1783 lek (1992) to 54270 lek (2015) or 30.4 times.

In this way, their dynamics is not only related to changes in the level of wages but also other factors mentioned above. Although revenue from PIThave been increasing, they do not have any weight in Total Budget Revenues, and Revenue from Taxes and Customs.

This dynamic is illustrated in the chart below. Percentage of PIT to TBR's was $0.3 \%$ in 1993 and $7.6 \%$ in the past in 2015. It increased by 25.3\%. Percentage of PIT to RTC's was 0.53 in 1993 and has gone $11.3 \%$ in 2015. It increased by $21.3 \%$. Although we have a high increase its weight to the RTC-is low. VAT compared to PITin 2015 was 4.3 times greater, excise 1.4 times etc.

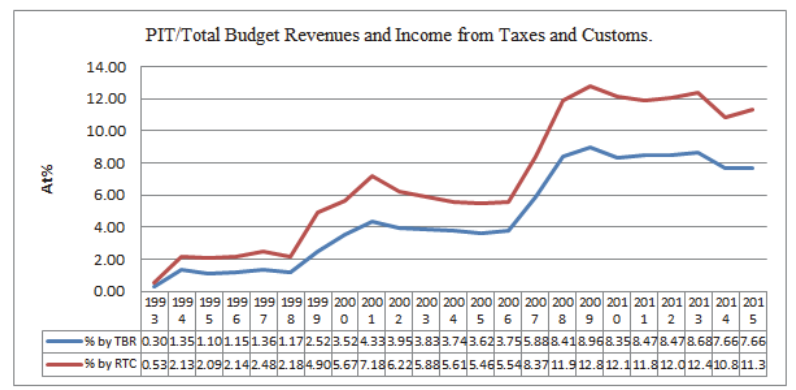

Chart 1. Percentage of Income from PIT to Total Budget Revenues and Income from Taxes and Customs.

The above conclusions stand in relation to GDP. This look from Table No. 10 and the corresponding graphs. 
Table 10. Dynamics of PITin billions, $\%$ and\% of GDP

\begin{tabular}{|ccccccccccccc|}
\hline No. & Naming & $\mathbf{1 9 9 4}$ & 1995 & $\mathbf{1 9 9 6}$ & $\mathbf{1 9 9 7}$ & $\mathbf{1 9 9 8}$ & $\mathbf{1 9 9 9}$ & $\mathbf{2 0 0 0}$ & $\mathbf{2 0 0 1}$ & $\mathbf{2 0 0 2}$ & $\mathbf{2 0 0 3}$ & $\mathbf{2 0 0 4}$ \\
\hline 1 & PIT billion ALL & $\mathbf{0 . 6}$ & $\mathbf{0 . 6}$ & $\mathbf{0 . 6}$ & $\mathbf{0 . 8}$ & $\mathbf{1 . 2}$ & $\mathbf{3 . 1}$ & $\mathbf{4 . 6}$ & $\mathbf{6 . 3}$ & $\mathbf{6 . 1}$ & $\mathbf{6 . 4}$ & $\mathbf{6 . 9}$ \\
\hline 2 & PIT \% of GDP & 0.2 & 0.2 & 0.2 & 0.2 & 0.3 & 0.7 & 0.9 & 1.1 & 1 & 0.9 & 0.9 \\
\hline 4 & PIT, growth in\% & 632.1 & 10.9 & 0.6 & 27.9 & 43.3 & 169 & 46.3 & 37.0 & -3.2 & 4.9 & 7.8 \\
\hline No. & Naming & $\mathbf{2 0 0 5}$ & $\mathbf{2 0 0 6}$ & $\mathbf{2 0 0 7}$ & $\mathbf{2 0 0 8}$ & $\mathbf{2 0 0 9}$ & $\mathbf{2 0 1 0}$ & $\mathbf{2 0 1 1}$ & $\mathbf{2 0 1 2}$ & $\mathbf{2 0 1 3}$ & $\mathbf{2 0 1 4}$ & $\mathbf{2 0 1 5}$ \\
\hline 1 & PIT billion ALL & $\mathbf{7 . 4}$ & $\mathbf{8 . 6}$ & $\mathbf{1 4 . 8}$ & $\mathbf{2 4 . 5}$ & $\mathbf{2 6 . 8}$ & $\mathbf{2 7 . 1}$ & $\mathbf{2 8}$ & $\mathbf{2 8}$ & $\mathbf{2 8 . 4}$ & 28.20 & 32.07 \\
\hline 2 & PIT \% of GDP & 0.9 & 1.0 & 1.5 & 2.2 & 2.3 & 2.2 & 2.2 & 2.1 & 2.1 & 2.0 & 2.1 \\
\hline 4 & PIT, growth in\% & 7.2 & 16.2 & 72.1 & 65.5 & 9.4 & 1.1 & 3.3 & 0.0 & 1.4 & -0.7 & 13.7 \\
\hline
\end{tabular}

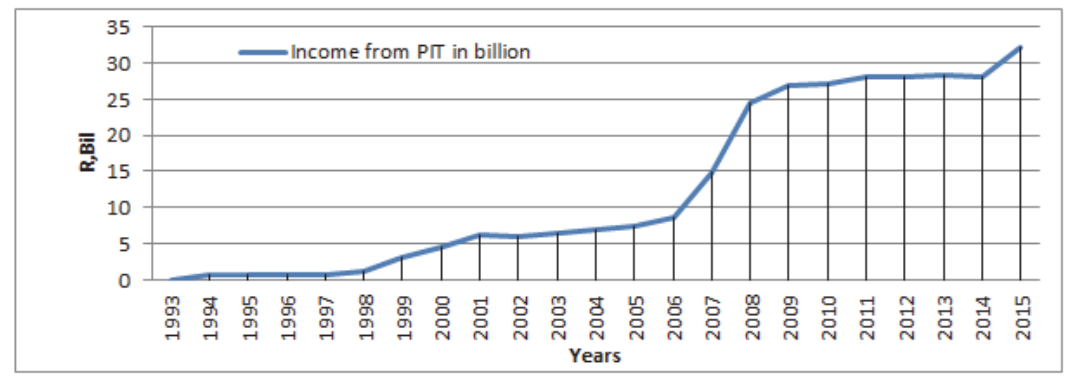

Chart 2. Income from PIT in billion

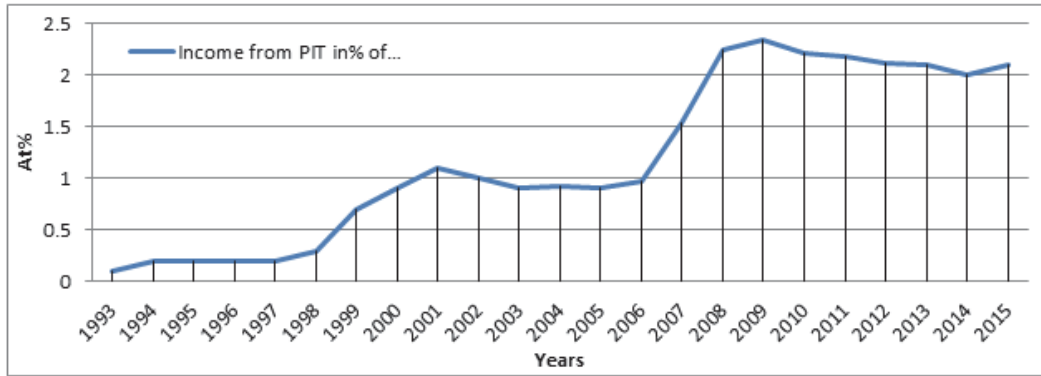

Chart 3. Income from PIT in\% of GDP

Correlative link between PIT and GDP in billion is: 0.970 . This figure shows that we have a very strong connection between the dynamics of nominal GDP with revenues from personal income tax.

The above dynamics is associated with changes in payroll periods as explained above: In 2000-2001, 2005-20062007 curve is steeper for growth is greater. In 2012 and the following have increased slightly, therefore the curve is almost straight. Here, in connection with the change of wages reflected the increased number of employees that are paid different salaries for their groups have not always changed at the same pace but their pace has changed. This explains the fact that the graph of the change in wages does not fully comply with the graph of Revenue by PIT.

Although the link between PIT and GDP in absolute is very strong relationship between the percentage of their growth is weak. This is explained by large changes in income from PIT over the years. The general trend of declining growth rate of GDP is almost uniform. The exceptions are 1997 and 2002 in which the decline is greater, and 2008 where growth is greater. The equation of this line is $Y=+17.01-0.7049 x$. Otherwise the problem with the line of income from PIT. In the years 1997-2001 and 2007-2008 have increased, while in other years have almost a uniform decline. In this graphic, they reflected the changes that have been made over the years, the wage level.

The link between PIT and GDP in\% given by the chart below. 


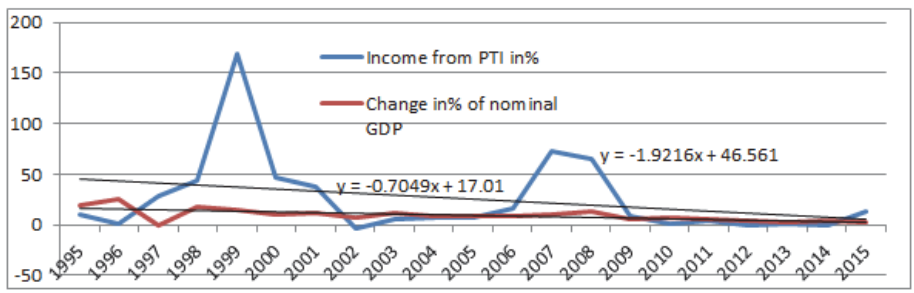

Chart 4. PIT and GDP dynamics in \%

Dynamics of the average wage in the public sector and the PIT is presented in Figure No. 5

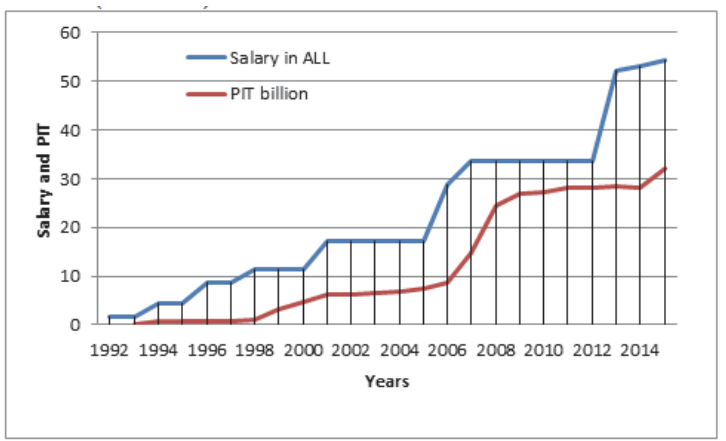

Chart 5. Dynamics of the average wage in the public sector and the PIT in billion (1992-2015).

The correlation coefficient between the average wage and income from PIT is 0928. This shows that between them have a very strong connection. But, irrespective of the position that takes the role it plays in total revenues from taxes it is not great. It comes after the VAT and Excise, which occupied the leading place.

The strong visual dynamics seen from the graph. When we have differences in salary, then also changes in tax revenue. Fluctuations coincide with the years that have made changes in the level of wages, 1992-1994-1996-19982001-2006-2007-2013-2014 and 2015. Cross Slope lines increased in periods when wage growth has been very high.

\section{Some Indicators Calculated of PIT, in Respect of Income}

In this section we analyze some effectual indicator which shows the place and the dynamics of PIT into three groups of revenue and to GDP. The goal is to see if there is any increase to $1 \mathrm{ALL}$ income? What place does this income to total? This relation is strong or weak?

The link between PIT and Total Budget Revenues, Revenues from Taxes Customs and in connection with nominal GDP is given in the following table and graph:

Table 11. Some indicators effectual

\begin{tabular}{|c|c|c|c|c|c|c|c|c|c|c|c|}
\hline Naming & 1994 & 1995 & 1996 & 1997 & 1998 & 1999 & $\mathbf{2 0 0 0}$ & $\mathbf{2 0 0 1}$ & $\mathbf{2 0 0 2}$ & $\mathbf{2 0 0 3}$ & $\mathbf{2 0 0 4}$ \\
\hline PIT/TBR(ALL) & 0.01 & 0.01 & 0.01 & 0.01 & 0.01 & 0.03 & 0.04 & 0.04 & 0.04 & 0.04 & 0.04 \\
\hline PIT/ Tax Income(ALL) & 0.02 & 0.02 & 0.01 & 0.02 & 0.02 & 0.04 & 0.04 & 0.06 & 0.05 & 0.04 & 0.04 \\
\hline PIT/RTC(ALL) & 0.02 & 0.02 & 0.02 & 0.02 & 0.02 & 0.05 & 0.06 & 0.07 & 0.06 & 0.06 & 0.06 \\
\hline PIT/GDP(ALL) & 0.00 & 0.00 & 0.00 & 0.00 & 0.00 & 0.01 & 0.01 & 0.01 & 0.01 & 0.01 & 0.01 \\
\hline Naming & $\mathbf{2 0 0 5}$ & $\mathbf{2 0 0 6}$ & $\mathbf{2 0 0 7}$ & $\mathbf{2 0 0 8}$ & $\mathbf{2 0 0 9}$ & $\mathbf{2 0 1 0}$ & $\mathbf{2 0 1 1}$ & $\mathbf{2 0 1 2}$ & $\mathbf{2 0 1 3}$ & $\mathbf{2 0 1 4}$ & $\mathbf{2 0 1 5}$ \\
\hline PIT/TBR(ALL) & 0.04 & 0.04 & 0.06 & 0.08 & 0.09 & 0.08 & 0.08 & 0.08 & 0.09 & 0.08 & 0.08 \\
\hline PIT/ Tax Income(ALL) & 0.04 & 0.04 & 0.06 & 0.09 & 0.10 & 0.09 & 0.09 & 0.09 & 0.09 & 0.08 & 0.09 \\
\hline PIT/RTC(ALL) & 0.05 & 0.06 & 0.08 & 0.12 & 0.13 & 0.12 & 0.12 & 0.12 & 0.12 & 0.11 & 0.11 \\
\hline PIT/GDP(ALL) & 0.01 & 0.01 & 0.02 & 0.02 & 0.02 & 0.02 & 0.02 & 0.02 & 0.02 & 0.02 & 0.02 \\
\hline
\end{tabular}




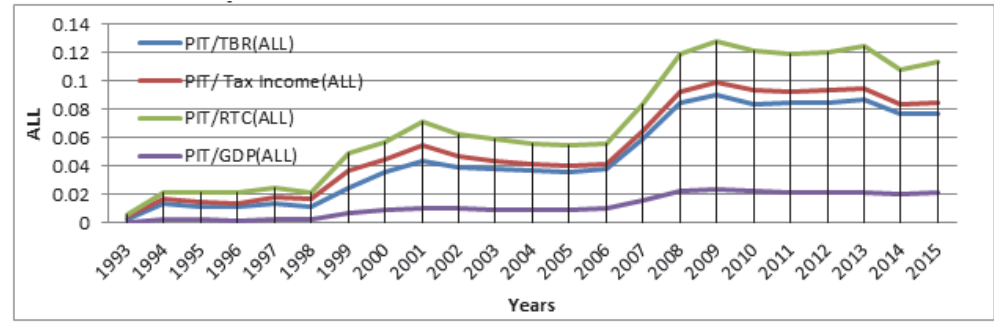

Chart 6. Dynamics of some indicators effectual.

Table data and graphs above show, that among these indicators calculated have strong ties because of their trends lines are almost the same, especially in the first three. Change in relation to nominal GDP, which is represented by the last line is fully connected to the first three. This is because the coefficient of correlation between nominal GDP and income from PIT was 0.970 .

The correlation coefficients between the first three indicators are:

$\begin{array}{ll}\text { PIT/TBR(ALL) with PIT/ Tax Income(ALL) } & 0.9973 \\ \text { PIT/TBR(ALL) with PIT/RTC(ALL) } & 0.9972 \\ \text { PIT/TBR(ALL) with PIT/GDP(ALL) } & 0.9973\end{array}$

The difference between them is only in size because the trend deviations are very small. This shows that PIT is important not only for the size of tax revenue and customs, but also in the size of the total budget revenues. Budget revenues have strong ties with budget expenditures. Budget expenditures are part of GDP, in item (G). In this way the relationship is also reflected in the correlation indicators that exhibited above. Budget revenues affecting the growth of operating costs, increase investments, but they also cause a further reduction of the budget deficit.

In recent years, the budget deficit was according to government forecasts, due to the reduction of budget expenditures and revenue growth. Policy towards fiscal system, in particular the fight against tax evasion, have given their fruits in revenue growth. In the future, according to submissions and analysis, more work should be done in the fight against tax evasion, rather than in terms of changing rates PIT. Their growth coincides with styptic fiscal policies, which are contrary to the expansionary monetary policy of the Central Bank, which has applied in recent years. If the government will see two roads, expanding base of tax payers, and the fight against informality and evasion, there was no need to increase and establish progressive tax, or changes every 2.8 years PIT. Increasing the tax rate is a theoretical limits, which is explained by the Laffer Curve. In this way, not every tax increase, leading to increased levels of income from them.

\section{Conclusions and Recommendations}

Albanian economy by the year 1990 has been a centrally planned economy. In this country everything was under a unified state plan. There was no concept of taxes, unemployment, supply and demand and the market in general. It was a party political system, there was no democracy, free initiative and private property. After 1990, Albania slip in a transition economy. New elections were organized pluralist commence privatization of the means of production, the different sectors of the economy and the financial sector. Adopted a Western legal framework, especially in the field of finance. In finance radical changes were made. Tax Department was created which collected revenue to enable the functioning of the new democratic state.

Although there were a lot of experience in the tax system they were adopted by tens of hundreds of laws. Taxes that more change has been PIT (Personal Income Tax). It has changed 9 times or once every 2.8 years. Glide from progressive tax on flat tax and progressive tax back. Income from it have been constantly increasing. This was due to the growth of average wages, staffing changes, the PIT rate increase, increasing the taxable base etc. Of its estimated revenue after VAT (surplus value-added tax) and excise tax revenues. In year 2015 it has occupied $11.3 \%$ of revenue from taxes and customs. It has given its significant contribution to the increase of budget revenues, and increased economy. This is reflected in its relationship with the group of indicators of income and nominal GDP. 


\section{Recommendations}

We recommend that in the future not intended but growth PIT:

- In the future, do not aim at increasing the rate of TAP.

- Increase the fight against informality and tax evasion.

- Increase the base of taxpayers.

- TAP Norme not change constantly. Fiscal policies to adapt to monetary policy. Because in recent years fiscal policy has not been consistent with monetary policy. Monetary policy has been highly expansionary fiscal policy has been and styptic. In this way. Their influence has not given the expected results in economic growth.

- Tax Administration employees to be trained not only as professionals but also on the behavior of economic entities. They should consider business as a partner and not as subject to the income levy.

- Minimum wage increase in the minimum vital function for Albania.

\section{References}

Bank of Albania. Statistical Report, April 2016.

Bank of Albania. Statistical Report 2015.

Bank of Albania. Statistical Report 2014.

Bank of Albania. Statistical Report 2013.

The Bank of Albania. Statistical Report 2011.

The Bank of Albania. Statistical Report 2010.

The Bank of Albania. Statistical Report 2008.

The Bank of Albania. Statistical Report 2006.

Bank of Albania. Annual Report of the Bank of Albania. 2015.

Bank of Albania. Annual Report of the Bank of Albania. 2004.

Bank of Albania. Annual Report of the Bank of Albania. 2002.

Bank of Albania. Annual Report of the Bank of Albania. 2000.

Bank of Albania. Annual Report of the Bank of Albania. 1998.

Bank of Albania. Annual Report of the Bank of Albania. 1996.

Bank of Albania. Annual Report of the Bank of Albania. 1994.

Ministry of Finance.. Fiscal Indicators Regarding Consolidated Budget 1993-2010.

Ministry of Finance. Revenues Regarding Consolidated Budget 1993-2010

Ministry of Finance. Revenues Regarding Consolidated Budget 2011-2015.

Ministry of Finance. Fiscal Statistics, Tetor 2014.

Adriatik Mateli. Tax system in Albania. Tirana 2016.

Official Bulletin. 1992-2013. Parliament Albany. 
